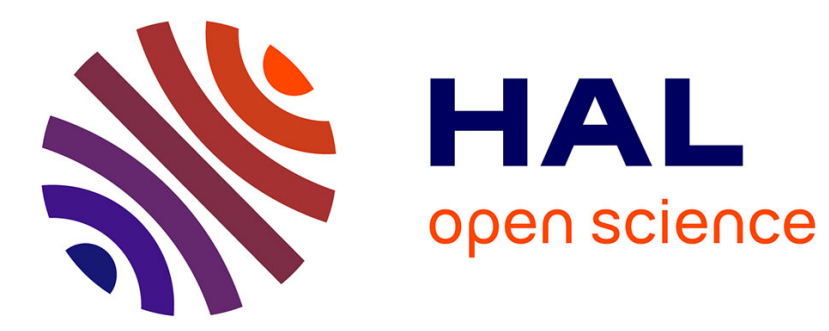

\title{
Impact of global warming on the growing cycles of three forage systems in upland areas of southeastern France
}

\author{
Stéphanie Juin, Nadine Brisson, Philippe Clastre, Pierre Grand
}

\section{To cite this version:}

Stéphanie Juin, Nadine Brisson, Philippe Clastre, Pierre Grand. Impact of global warming on the growing cycles of three forage systems in upland areas of southeastern France. Agronomie, 2004, 24 (6-7), pp.327-337. 10.1051/agro:2004028 . hal-00886029

\section{HAL Id: hal-00886029 \\ https://hal.science/hal-00886029}

Submitted on 1 Jan 2004

HAL is a multi-disciplinary open access archive for the deposit and dissemination of scientific research documents, whether they are published or not. The documents may come from teaching and research institutions in France or abroad, or from public or private research centers.
L'archive ouverte pluridisciplinaire HAL, est destinée au dépôt et à la diffusion de documents scientifiques de niveau recherche, publiés ou non, émanant des établissements d'enseignement et de recherche français ou étrangers, des laboratoires publics ou privés. 


\title{
Impact of global warming on the growing cycles of three forage systems in upland areas of southeastern France
}

\author{
Stéphanie JUIN ${ }^{a *}$, Nadine BrissON ${ }^{\mathrm{a}}$, Philippe ClASTRE, Pierre GRAND \\ ${ }^{a}$ Département Environnement et Agronomie, Unité Climat Sol et Environnement, INRA, Site Agroparc, 84914 Avignon, Cedex 9, France \\ ${ }^{\mathrm{b}}$ Chambre d'Agriculture des Hautes Alpes S.J. INRA, Unité CSE, Ribiers, 05000 Gap, France
}

(Received 16 June 2003; accepted 6 February 2004)

\begin{abstract}
The simulations supplied by a combination of a global climate model and a weather generator allowed the creation of two climate scenarios including an increase and/or monthly variations in temperature for the 2070-2100 horizon, which were compared with two currently available series (1961-1990 and 1990-2000). Three forage systems applied in upland areas of southern France were simulated using the STICS model (silage maize, perennial alfalfa and grasses) and the outputs were introduced into a digital elevation model. We noted changes in precocity which allowed the sowing of silage maize varieties with longer crop cycles at lower altitudes and an enlargement of the crop zone above 700-800 m. When introducing monthly temperature variations, we observed major frost damage which decreased maize yields. As for gramineous and alfalfa grasslands, we obtained a lengthening in the growing period with earlier first cut dates and sometimes the possibility of a supplementary cut.
\end{abstract}

climatic change / silage maize / alfalfa, gramineous / upland area / crop model

\section{INTRODUCTION}

The rise in atmospheric $\left[\mathrm{CO}_{2}\right]$ levels, together with increases in other greenhouse gases (mainly $\left[\mathrm{CH}_{4}\right]$ and $\left[\mathrm{N}_{2} \mathrm{O}\right]$ ) are predicted to produce global warming of the terrestrial surface. In the third report of the Intergovernmental Panel on Climate Change [21], the experts noted that the land-surface air temperature rose by between $0.4{ }^{\circ} \mathrm{C}$ and $0.8{ }^{\circ} \mathrm{C}$ in global average during the 20th century, with an acceleration of this phenomenon during the last decade. According to the projections of climate models or GCMs (General Circulation Models), average global warming will range between 1.4 and 5.8 degrees Celsius by the end of this century, depending on our ability to regulate the output of greenhouse gases [21].

Thanks to improvements in GCM accuracy, both in terms of time step and spatial resolution [37], the use of climatic scenarios is now practicable for impact studies [4].

At the same time, agronomic models have been developed [45], which comprehensively integrate the effect of climate on crop production in interactions with soil and crop management. Those models constitute appropriate tools for the prospective investigation of climate impact on agriculture [34,36]. It is particularly important to determine whether climate change is likely to have a profound effect on cropping systems, knowing that a broad range of scenarios can be considered [12], coupling climatic and agricultural scenarios (land use, cropping systems, etc.). With this in mind, we decided to study forage crops in less favorable farming areas, firstly because of the carbon storage potential of such crops, particularly of a perennial type (with reference to the Kyoto protocol), and secondly because of the potential value of such regions to European agricultural policy.

We limited our study to the impact of temperature increases, and did not take account of changes to any climatic variables or direct effects (e.g. $\left.\left[\mathrm{CO}_{2}\right]\right)$. There were numerous reasons for this choice. Firstly, there is broad scientific agreement on global warming, which has been predicted by numerous numerical climatic models [24], even if discrepancies remain between these models with respect to the average level of thermal elevation. It is far less clear for the other variables, especially concerning rainfall [24], for which models may diverge significantly; for this reason, it is somewhat hazardous to base impact studies on such uncertain trends. A further reason is that the currently available climatic series, on both the global [21] and regional scales [33] include marked thermal elevation, thus corroborating observations of regular advances in the phenological stages of natural or cultivated plants, as well as birds and insects [3, $8,25,32]$. Even if greenhouse gas emissions cease, warming will continue, mainly because of the buffer role of oceans. Thus the warming we are currently experiencing probably originated during the early decades of mass industrialization, towards the end of the 19th century. The credibility of GCM findings in terms of global warming has recently been proved by comparing long climatic series with model results [33]. Increases in

* Corresponding author: juin@ avignon.inra.fr 
$\mathrm{CO}_{2}$ concentrations, which currently reach around $370 \mathrm{ppm}$, are much more uncertain and dependent on gas emission regulation policies, even though the ocean buffer is also relevant to $\left[\mathrm{CO}_{2}\right]$ [23]. Climatic model experts explain such time shifts between $\left[\mathrm{CO}_{2}\right]$ and temperature elevations by the fact that we are currently in a transition phase, a steady state not having been attained as yet.

One advantage of crop models is that they can analyze the impact of thermal increases independently of other perturbations. Such models include the biophysical responses of plantsoil systems to climatic variables with a daily time step, and temperature plays a central role in this respect because it acts on a variety of processes: phase development [31], photosynthesis and respiration which drive growth, soil mineralization [35] and water requirements, through the calculation of potential evapotranspiration.

Nevertheless, for most of those processes, temperature interacts with other climatic variables such as radiation, rainfall or atmospheric moisture; the only exception is phase development, which is almost exclusively thermally driven (although some retroactions with growth may occur under severe stress conditions). This, together with the strategic importance of crop-cycle durations, led us to focus our study on phasic development. The few results given with respect to yield apply to the grain-filling duration of maize crops.

In terms of phasic development, previous studies [13, 30] showed that global warming would affect the length of the growing season. For annual crops with determined cycles, vegetation cycles would be shortened, resulting in reduced yields: this negative relationship between temperature and yield has recently been demonstrated with real-time data in the USA [26]. In contrast, the vegetation period of perennial crops (or indeterminate species) would be longer, thus allowing an earlier start of the growing cycle in spring and ending later in the autumn.

In mountain zones, because of amplifications due to the thermal gradient at altitude, climate change would probably be more rapidly visible, and thus result in an upwards migration of vegetation zones. However, if the growing period starts earlier, crops will be more vulnerable to spring frosts [44]. For forage crops, such changes would have a direct effect on crop management, with the earlier grazing of herds in spring or an increase in the number of cuts. To prove that global warming has already started, farmers in the studied zone have been growing silage maize in higher altitude areas for the past ten years [35].

Our study aimed to assess the impact of climate warming on the cropping calendar and spatial distribution of forage crops in a traditional grassland area located in the uplands of southeastern France. The methodology was based on the combined use of the crop model STICS [7], GCM output data, stochastic weather data generation and the findings from two current climate series. Three forage systems were considered, concerning gramineous, legume and maize crops.

\section{MATERIALS AND METHODS}

\subsection{The study area}

The study area is located at $44^{\circ} \mathrm{N}, 6^{\circ} \mathrm{E}$ in the alpine Provencal region of southeastern France. The area concerned covers roughly $4000 \mathrm{~km}^{2}$, with altitudes ranging from 450 to 1550 meters.
The majority of farming activities are devoted to livestock. Grassland areas cover $75 \%$ of agricultural land in the region, with $15 \%$ devoted to forage, principally of legume or gramineous crops. Silage maize is grown on $2.6 \%$ of the forage surface area, but its proportion has been rising continuously over the past ten years (1.9\% in 1988).

\subsection{Tools and data on climate}

The study was based on current and future series generated by climate models, including a GCM and a weather generator. In order to have realistic data on the study region as a whole, we separated the zone component of climate from its altitude component. While the zonal component was covered by data series from two operational meteorological stations located in the southern and northern parts of the region, the altitude component was determined using an empirical thermal gradient model.

\subsubsection{Current data}

The two meteorological stations are Briançon (in the northern part of the region, at an altitude of $1320 \mathrm{~m}$ ) and Saint Auban (in the south, at an altitude of $440 \mathrm{~m}$ ). The climatic series covered the period 1961-2000 and comprised standard climatic variables: solar radiation, minimum and maximum daily temperatures, precipitation and reference evapotranspiration.

Following the diagnosis made by IPCC experts [21], each series of climatic data was divided into two periods. The first period (series 1), between 1961 and 1989, was considered as a reference or historic series unaffected by climate change, and the second (series 2), between 1990 and 2000, was considered as a recent series, during which period climate change is supposed to have started.

An empirical model (Altitude Thermal Gradient Model or ATGM) was developed based on simplified assumptions on air mass behavior in a mountainous region and bibliographic results, efforts being made to include the local topography which is known to influence mountain climate [1, 2, 16, 27]. We first assumed a regular fall in temperature as altitude increased $\left(-0.55^{\circ} \mathrm{C}\right.$ per $100 \mathrm{~m}$ for minimum temperatures and $-0.61{ }^{\circ} \mathrm{C}$ per $100 \mathrm{~m}$ for maximum temperatures, according to [14]). Secondly, in order to account for orientation, the thermal gradient applied to maximum temperatures for north-facing slopes was lowered by $1.4{ }^{\circ} \mathrm{C}$ when compared with south-facing slopes $[2,5,14]$. Thirdly, under clear weather conditions, cold air flows concentrate in mountain valleys during the night, resulting in a climate inversion process $[10,27]$. We assumed the upper limit of this process to be $700 \mathrm{~m}$ and that this could be simulated as an upward thermal gradient increase of $1.3{ }^{\circ} \mathrm{C}$ per $100 \mathrm{~m}$ for minimum temperatures only, thus counter-balancing the regular gradient. Clear weather conditions were determined from the cloud fraction value, calculated using the Angström formula [20], with an $80 \%$ threshold.

\subsubsection{Future data}

To form a basis for the calculation of future climate scenarios, we used daily outputs of the LMD (Laboratoire de Météorogie Dynamique) - GCM [4] for two assumptions of atmospheric $\mathrm{CO}_{2}$ concentration: $360 \mathrm{ppm}$, supposed to be the 
Table I. Phenological parameterization for alfalfa, gramineous crops and silage maize. Gramineous values obtained from data concerning both the cocksfoot and tall fescue species and considered as a generic parameterization.

\begin{tabular}{|c|c|c|c|c|}
\hline Crop & Alfalfa & Gramineous & \multicolumn{2}{|c|}{ Silage maize } \\
\hline Temperature base & $5^{\circ} \mathrm{C}$ & $0^{\circ} \mathrm{C}$ & \multicolumn{2}{|c|}{$6{ }^{\circ} \mathrm{C}$} \\
\hline \multirow{3}{*}{$\begin{array}{l}\text { Typical growing period duration in } \\
\text { phenological units (degree-days } \\
\text { accounting for photoperiod and } \\
\text { vernalization effects) }\end{array}$} & \multirow{2}{*}{$\begin{array}{c}\text { Emergence - beginning } \\
\text { budding }\end{array}$} & \multirow[t]{2}{*}{ Emergence - beginning heading } & \multicolumn{2}{|c|}{ Emergence - silage maturity } \\
\hline & & & DEA & Volga \\
\hline & 380 & 400 & 1798 & 1526 \\
\hline Beginning frost temperature & $2{ }^{\circ} \mathrm{C}$ & $1^{\circ} \mathrm{C}$ & \multicolumn{2}{|c|}{$5^{\circ} \mathrm{C}$} \\
\hline Lethal temperature & $-20^{\circ} \mathrm{C}$ & $-30^{\circ} \mathrm{C}$ & \multicolumn{2}{|c|}{$-4^{\circ} \mathrm{C}$} \\
\hline $\mathrm{T}_{10}$ & $1{ }^{\circ} \mathrm{C}$ & $0{ }^{\circ} \mathrm{C}$ & \multicolumn{2}{|c|}{$4^{\circ} \mathrm{C}$} \\
\hline $\mathrm{T}_{90}$ & $-4^{\circ} \mathrm{C}$ & $-10^{\circ} \mathrm{C}$ & \multicolumn{2}{|c|}{$0^{\circ} \mathrm{C}$} \\
\hline Phyllotherme in degree-days & 83 & 220 & \multicolumn{2}{|c|}{55} \\
\hline
\end{tabular}

current level and $720 \mathrm{ppm}$, supposed to be the future level (the steady state being assumed to be attained for the 2070-2100 thirty-year series). Monthly values for averages and standard deviations of minimum and maximum temperatures were then derived in order to estimate any anomalies between current and future climate data applied to series 1 . We preferred this socalled "anomaly" method mainly because the broad resolution of the LMD model did not allow the differentiation of zones within the study region: one $250 \times 250 \mathrm{~km}^{2}$ pixel of the LMD model covered the entire region. Anomalies consisted of $\mathrm{P}_{1}$, representing the difference between the average mean daily temperatures of the two calculated series (360 and $720 \mathrm{ppm}$ ), and $\mathrm{P}_{2}$, being the ratio between standard deviations of mean temperatures in both series. The $\mathrm{P} 1$ and $\mathrm{P} 2$ vectors, put in order over the 12-month period, were: $\mathrm{P}_{1}=(1.8,1.0,1.7,1.7,2.4$, $1.1,1.9,1.6,2.3,2.3,1.4,0.9)$ and $\mathrm{P}_{2}=(0.9,1.2,0.9,1.1,1.3$, $0.7,1.5,1.2,1.4,0.9,0.6,0.9)$. These anomalies were applied to the current series with a weather generator taking account of the stochastic character of climate data.

Use of the anomaly method with daily average temperatures assumes that the greenhouse effect is similar for minimum and maximum temperature, which is not really the case. Nevertheless the differences between Tmin and Tmax increases remain below $0.5^{\circ} \mathrm{C}$ except for September $\left(1.08^{\circ} \mathrm{C}\right)$. This is a drawback of the method, which has little impact on the model because the active temperature is mostly the daily average. One exception is the simulation of responses to freezing minimum temperatures, although this may be somewhat exaggerated.

The LARS-WG weather generator [40] is a stochastic model that aims to calculate synthetic daily time series of maximum and minimum temperatures, precipitation and solar radiation statistically from an observed series. It is capable of accounting for modifications to monthly averages and standard deviations of the above variables. The originality of the LARS weather generator lies in its independent monthly computations of dry and wet day series [28, 41]. Temperatures and radiation levels are split into two groups according to the wet or dry status of the day and fitted to a semi-empirical distribution. Climatic anomalies are introduced month by month to adjust the distribution of temperature. The reliability of its results are evaluated by comparing actual and calculated averages and standard deviations in the series using the Student and Fischer tests.
For our study, two scenarios were generated by LARS, one (scenario 1) taking account of temperature increases only $\left(\mathrm{P}_{1}\right)$ and the other (scenario 2) including both temperature increases $\left(\mathrm{P}_{1}\right)$ and changes to monthly standard deviations $\left(\mathrm{P}_{2}\right)$.

It is important to note that the ATGM was applied to both the current and simulated climate series.

\subsection{Tools and data concerning crops}

\subsubsection{Simulated cropping systems}

The choice of cropping systems involving the use of appropriate techniques relied on local technical studies [18]. Three forage systems were simulated using the STICS crop model: legume grassland composed of alfalfa, gramineous grassland assumed to be composed of a mixture of cocksfoot and tall fescue, and silage maize. Two maize varieties were considered, a variety with a short cycle (DEA) and another with a long cycle (Volga). The grassland crops were assumed to be perennial and we did not consider a sowing year simulation, while two sowing dates were assumed for silage maize: May 15 and April 15 for the short- and long-cycle varieties, respectively.

To avoid severe water stress (outside the scope of this phenological study), realistic irrigation was assumed, which consisted of meeting $50 \%$ of water requirements for grasslands with 20 -mm irrigation doses and $70 \%$ for maize with $40-\mathrm{mm}$ doses. The grasslands were not fertilized, while the maize was assumed to receive $80 \mathrm{kgN} \cdot \mathrm{ha}^{-1}$ at sowing and another $60 \mathrm{~kg} \cdot \mathrm{ha}^{-1}$ on June 20.

For alfalfa and gramineous crops, mowing cuts were scheduled at optimum dates in terms of forage quality, i.e. just before budding for alfalfa and heading for gramineous crops (inter-cut intervals are shown in Tab. I), and the height of the cut taken was $10 \mathrm{~cm}$ (in the model, empirical relationships allow the translation of this cut height in terms of initial biomass and leaf area index). The maize growing cycle was not allowed to extend beyond November 15 .

The same soil was assumed for the whole region: two horizons of, respectively, 20 and $30 \mathrm{~cm}$ thickness, with field capacities, wilting points (in $\mathrm{g}$ water/g soil) and bulk density of $20.5 \%, 19.5 \%, 9 \%, 9 \%, 1.4$ and 1.5 , respectively. The organic 
nitrogen content was taken to be $0.15 \%$. This region is typified by shallow soil, the effect of which is minimized by irrigation.

\subsubsection{General presentation of the STICS crop model}

STICS (Simulateur mulTIdisciplinaire pour les Cultures Standards) is an interactive modeling platform which has been developed by INRA since $1996[7,9]$ according to generic principles and can therefore simulate numerous crops. During this study, we applied the parameters for maize [7, 43], gramineous forage $[17,38,46]$ and alfalfa $[22,39]$.

STICS simulates crop growth and yield as well as soil water and nitrogen balances, driven by daily climatic data and taking account of crop management systems. The required inputs are daily climate data, permanent soil characteristics and cropping techniques.

\subsubsection{Description of the principal STICS functionalities used in this study}

A full description of the model can be found in [7] and [9]. The principal driving modules in the particular case of this study are detailed hereafter.

Two phenological scales are simulated: vegetation and reproduction. The duration of each phase between emergence and physiological maturity is expressed in growing degreedays (see Tab. I for parameters) that may be influenced by a photoperiodic or a vernalization limiting factor [7]. The latter effect was just active for gramineous crops, and vernalization was assumed to start on October 1st, in the knowledge that vernalization requirements are expected to be lower than for winter wheat. As traditional temperate long-day crops, the photoperiodic response of alfalfa and gramineous crops was assumed to be the same as for wheat [7]. The temperature used to calculate degree-days was the crop temperature resulting from driving climatic variables, on the one hand, and evapotranspiration from the water balance on the other hand. As the scheduled crop management system minimized water stress, this temperature equaled the air temperature.

During this study, frost was considered to be a significant limiting factor because of the combination of earlier expected spring vegetation and the upland context. For this reason, a new module was developed for STICS to simulate frost damage to crop growth, according to the minimum temperature. We assumed the different effects of freezing temperatures according to current crop stages. Between crop emergence and the plantlet stage (arbitrarily assumed to be the 3-leaf stage, knowing that leaf stages are calculated with a constant phyllotherme), frost kills plants and the result is a reduction in plant density. During subsequent stages, frost causes necrosis, resulting in a decrease in leaf surface area. The degree of damage is calculated using four threshold temperatures: $\mathrm{T}_{\text {beg }}, \mathrm{T}_{10}, \mathrm{~T}_{90}$, and $\mathrm{T}_{\text {let. }}$ corresponding, respectively, to the onset of frost damage, $10 \%, 90 \%$ and $100 \%$ (death) damage. These thermal thresholds are crop-specific and $\mathrm{T}_{10}$ and $\mathrm{T}_{90}$ may differ depending on the phase. Between these thresholds, the frost effect is assumed to be linear (see Tab. I for parameters [6, 15, 19, 29, 42]).

\subsubsection{Model outputs, computation procedures and mapping techniques}

For mowed forage crops, the outputs considered were first cutting dates and the numbers of cuts allowed during the growing season. As far as maize silage was concerned, optimum sowing dates (assessed as optimum emergence dates minus 10 days), harvesting dates, the number of years when crops could not reach silage maturity before November 15 and yield were all investigated.

Statistical tests (Fisher test at 95\%) were performed to test the significance of the results from recent and simulated series by comparison with historic series, used as a reference.

Computations were performed in a precise order:

Selection from the GIS ARCINFO (CEsri) and a digital elevation model with a $75 \times 75 \times 10 \mathrm{~m}$ resolution of the upland areas located between altitudes of 450 and $1550 \mathrm{~m}$.

Assignment of each cell to the appropriate climatologic zone.

Use of the cell orientation calculation procedure to classify cells according to binary dichotomy (north and south by -90 to +90 scanning of the area).

STICS runs for two meteorological sites (Briançon and St Auban) $\times 4$ climatic series (current climate with historic and last ten-year series and the two climate change scenarios) $\times 11$ altitudes (altitude sampled every $100 \mathrm{~m}$ from 450 to $1550 \mathrm{~m}$ ) $\times 2$ orientations (north and south).

In order to spatialize the simulation results, the STICS output matrix was inserted into the GIS.

The GIS also allowed the calculation of area statistics for the principal output variables.

\section{RESULTS AND DISCUSSION}

\subsection{Climate}

Comparison of the two real series and the two scenarios for the Briançon weather station (Fig. 1) showed increases in the mean annual temperature between the historic series (around $7.6^{\circ} \mathrm{C}$ ), the last ten-year series (around $8.4^{\circ} \mathrm{C}$ ) and the simulated series (around $9.3^{\circ} \mathrm{C}$ ). Examination of the data for the last three years (2001 to 2003), not included in the study, showed that this trend was pursued.

In order to evaluate the ATGM empirical model, in the knowledge that no relevant meteorological data were available for the upland region under study, an indirect validation was performed by comparing the dates of phenological stages simulated with STICS with the equivalent observed dates available for alfalfa (beginning of the flowering stage) and grass crops (beginning of the heading stage) for different altitudes within the studied zone (Fig. 2). The results were even more satisfactory, in that the temperature used in the model accurately predicted the phenological stages.

As far as the climatic generator is concerned, Semevonov et al. [41] pointed out that LARS has difficulties reproducing inter-year variations in mean climate variables having an effect on the distribution of frost and hot spells. Mavromatis et al. [28] established that LARS-WG underestimates variations in monthly 


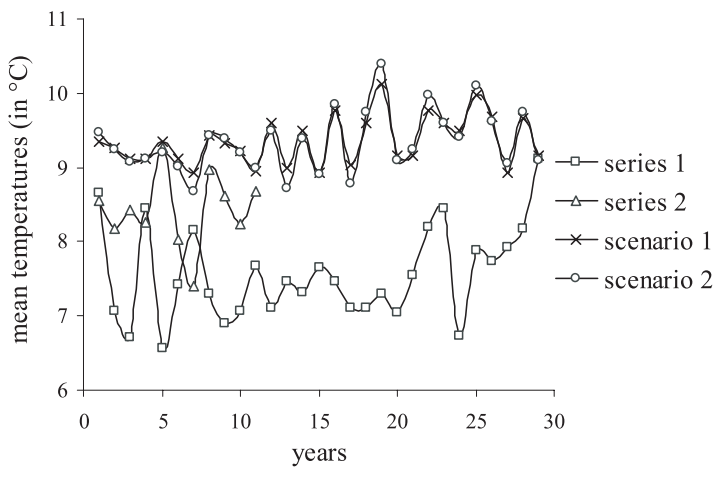

Figure 1. Mean annual temperatures at the Briançon meteorological station: observed (series 1 and 2) and simulated temperatures provided by a combination of LMD-GCM outputs and LARS weather generator data (scenarios 1 and 2).

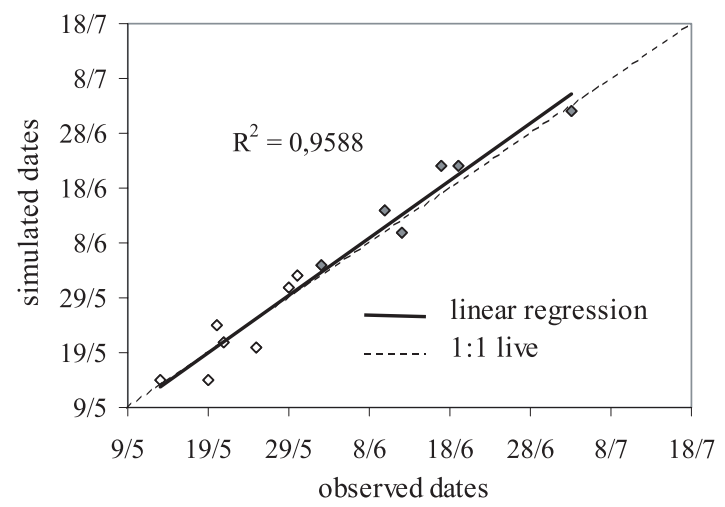

Figure 2. Phenological validation of the Altitude Thermal Gradient Model: comparison of simulated and observed phenological occurrence dates for altitudes between 500 and $1130 \mathrm{~m}$ in the Alps between 1970 and 1987 ( $\diamond$ heading for gramineous crops, $\bullet$ beginning of flowering for alfalfa).

temperatures, leading to an underestimation of the standard deviations of simulated crop responses. This problem in reproducing extreme temperature events was a drawback in our study, because it probably gave rise to an underestimation of frost damage and hot temperatures.

\subsection{Silage maize crops}

All results obtained using the crop model demonstrated the influence of altitude through simulation of the altitude thermal gradient. Another general result was that the last ten-year series displayed intermediate results between the historic series and the climate change scenarios (Figs. 3 and 4), though these differences were not always statistically significant (as in Fig. 3b).

The differences in optimum sowing dates between short(DEA) and long-cycle (Volga) varieties of maize were more marked at lower altitude (Fig. 3) than on uplands, resulting in a sowing altitude gradient which was nearly three times higher for Volga (2-3 days per $100 \mathrm{~m}$ ) than for DEA (1 day per $100 \mathrm{~m}$ ) in the historic series.

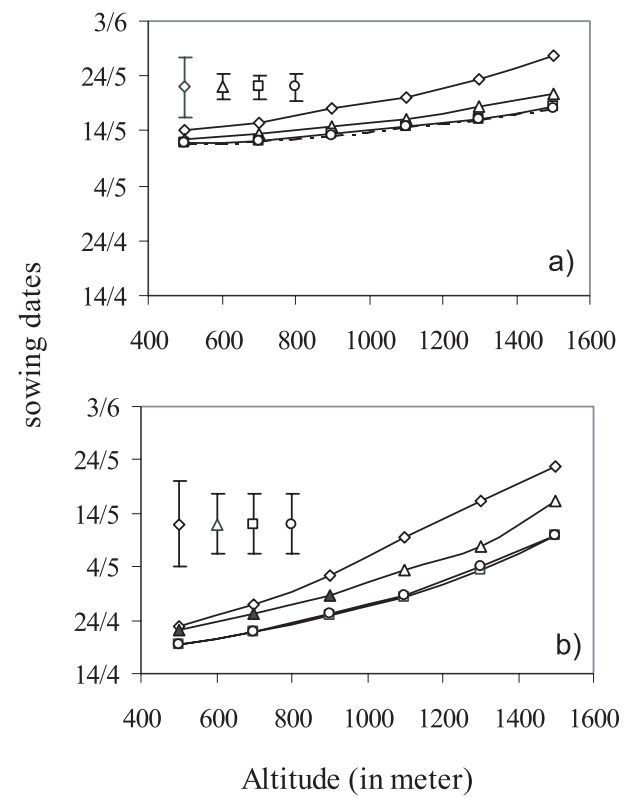

Figure 3. Evolution of sowing dates as a function of altitude for two silage maize varieties and of meteorological data collected by the Briançon Station (historic series $(\diamond)$, last ten-year series $(\triangle)$ ), scenario 1 ( $\square)$ and scenario $2(O)$, the full symbol corresponds to there being no significant difference with the historic series: (a) DEA, (b) Volga).



Figure 4. Evolution of harvest dates as a function of altitude for two silage maize varieties and of meteorological data collected by the Briançon and St Auban Stations (historic series $(\diamond)$, last ten-year series $(\triangle)$, scenario $1(\square)$ and scenario $2(O)$, the full symbol corresponds to there being no significantly different average comparison test: (a) DEA, Briançon, (b) DEA, St Auban, (c) Volga, Briançon, (d) Volga, St Auban).

The two simulated scenarios produced similar results, but taking account of changes in climatic variability in scenario 2 may have influenced the significance of the results (as in 3a).

At lower altitudes, below 700-800 m, the model predicted differences in harvesting dates of about 10-15 days, depending on the geographical zone or precocity (Fig. 4), which amplifies the timing of optimum sowing dates. At altitudes of $800 \mathrm{~m}$ and 
Table II. Percentage of maize silage surfaces harvested before and after October 17 for two varieties.

\begin{tabular}{lcccc}
\hline Variety & \multicolumn{2}{c}{ DEA } & \multicolumn{2}{c}{ Volga } \\
Harvest & Series 1 & Scenario 1 & Series 1 & Scenario 1 \\
\hline Before October 17 & 38.57 & 70.94 & 23.89 & 54.27 \\
After October 17 & 61.43 & 29.06 & 76.11 & 45.73 \\
\hline
\end{tabular}

above, the results from the last ten-year series were closer to the historic series, and the upper limit for crop growth was always less than $1500 \mathrm{~m}$ (where maturity cannot be attained before the latest harvesting date of November 15).

In terms of risks, Figure 4 clearly shows that the risks of harvesting maize before silage maturity diminished between the historic and the last ten-year series at altitudes below $900 \mathrm{~m}$, which would thus tend to increase the regional potential for long-cycle varieties. At higher altitudes, these risks remained incompatible in the northern zone, as from $1300 \mathrm{~m}$ and $1100 \mathrm{~m}$ with use of the short- and long-cycle varieties, respectively. The scenarios demonstrated a global reduction in these risks, resulting in a potential enlargement of the region where silage maize could be cultivated at high altitude. Table II and Annex A demonstrate a gradual extension of the potential maize crop zone, from the historic series to future scenarios, the results for the last ten-year series being intermediate. The harvesting date would be even earlier, with an even narrower fringe at high altitude where the crops could not reach maturity. The introduction of modifications in variability (scenario 2 ) had no impact on these phenological results, as is also shown in Table II. In addition to the increase in surface, climate change would allow more frequent use of long-cycle varieties.

Growing a long-cycle variety enabled an increase in yield (Fig. 5) but production was also more variable. Taking account of climatic variability modifications in scenario 2 induced a marked reduction in yield because of frost damage during the crop cycle.

\subsection{Forage crops}

As for perennial forage crops, the start of a farmer's cropping calendar is the first cut in spring, which may also be the first time that animals are able to graze. For both gramineous and alfalfa crops, and whatever the climatic series, Figure 6 shows that there was a constant altitude gradient from $500 \mathrm{~m}$ in the north and $700 \mathrm{~m}$ in the south, corresponding to a delay of about

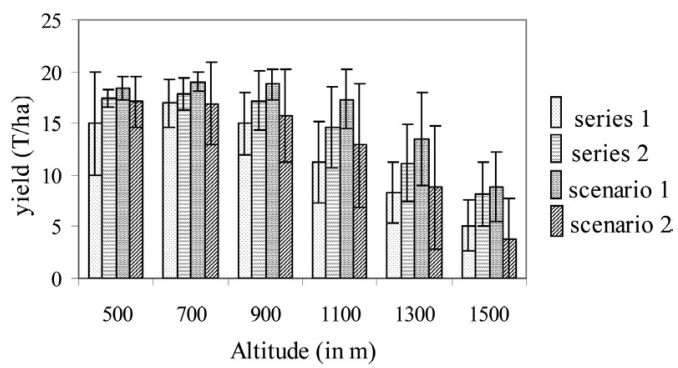

Figure 5. Yield as a function of altitude for the Volga silage maize variety and of meteorological data collected by the Briançon Stations.

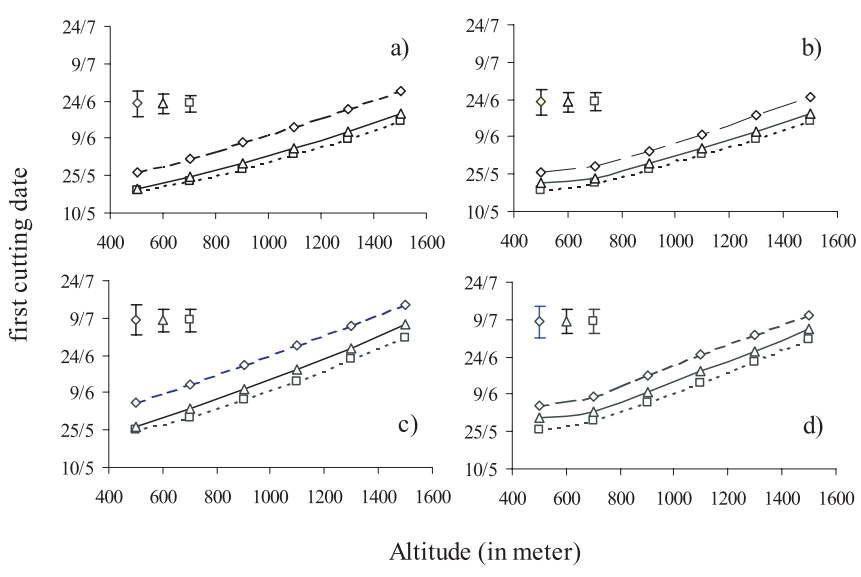

Figure 6. Evolution of first cut dates as a function of for alfalfa and gramineous crops and of meteorological data collected by the Briançon and St Auban Stations (historic series $(\diamond)$, last ten-year series $(\triangle)$ and scenario $1(\square)$, the full symbol corresponds to there being no significantly different average comparison test: (a) gramineous, Briançon, (b) gramineous, St Auban, (c) alfalfa, Briançon, (d) alfalfa, St Auban)

differences between the climatic series, suggesting once more a homogenization in the context of climate change.

Table III (Annex B) shows the expected evolution between the historic series and simulated scenario 1 . The late first cut (or first grazing) zones (after July 9) would also disappear and an advance of 10 to 20 days could be expected, depending on location and orientation. For these crops, the forage potential

Table III. Percentage of grassland surfaces as a function of the first cutting dates.

\begin{tabular}{|c|c|c|c|c|c|c|}
\hline \multirow{2}{*}{$\begin{array}{l}\text { Crop } \\
\text { First cutting date }\end{array}$} & \multicolumn{3}{|c|}{ Alfalfa } & \multicolumn{3}{|c|}{ Gramineous } \\
\hline & Series 1 & Series 2 & Scenario 1 & Series 1 & Series 2 & Scenario 1 \\
\hline Before June 9 & 5.40 & 18.97 & 28.13 & 35.41 & 52.24 & 65.39 \\
\hline Between June 9 and July 9 & 74.06 & 71.98 & 68.09 & 63.99 & 47.16 & 34.01 \\
\hline After July 9 & 20.54 & 9.05 & 3.78 & 0.60 & 0.60 & 0.60 \\
\hline
\end{tabular}



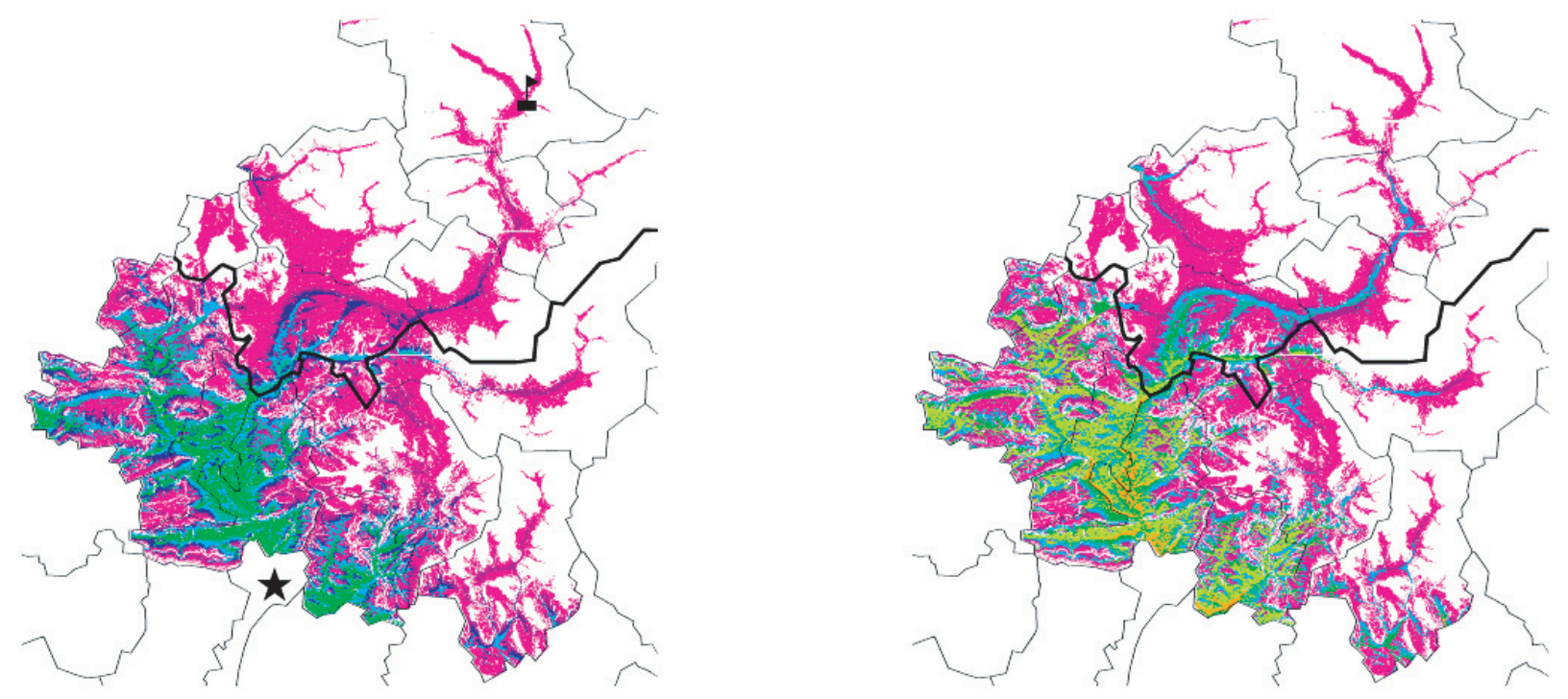

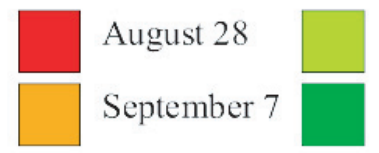

September 17

September 27

$\mathrm{c}$

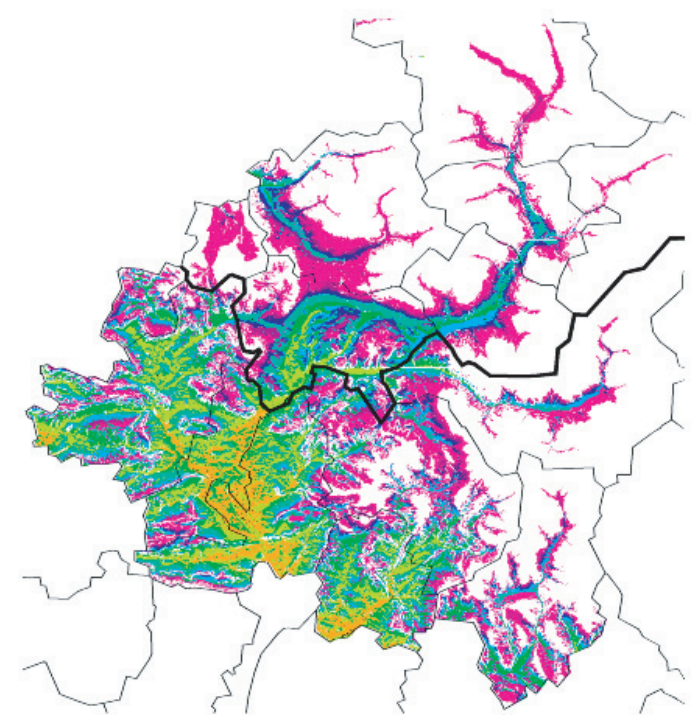

October 7

October 17

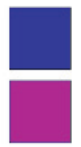

October 27

November 6
November 16

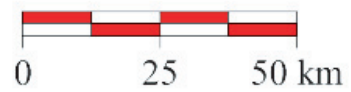

d

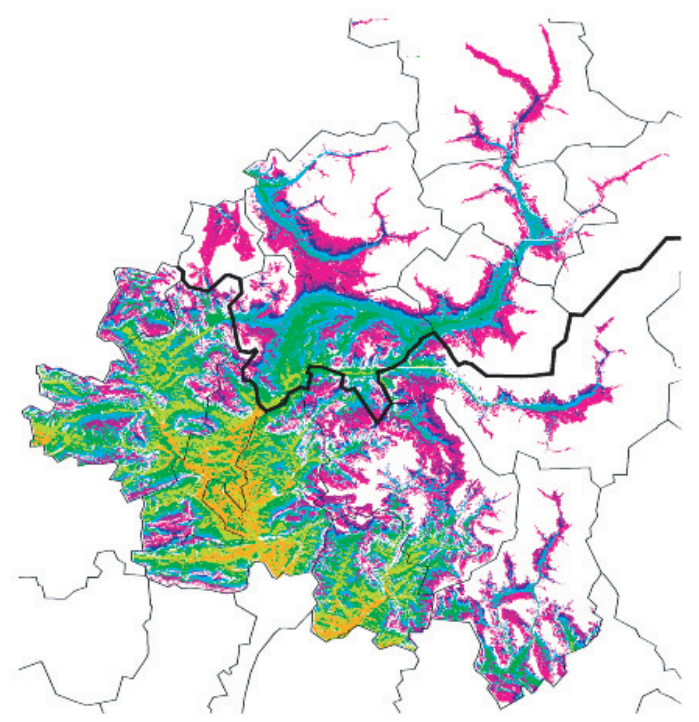

Annex A. Potential spatialized simulated harvesting dates for a long-cycle maize variety: (a) historic series, (b) last ten-year series, (c) scenario 1, (d) scenario 2. The bold line separates northern and southern zones. The flag and the star locate, respectively, Briançon and St Auban meteorological stations. 
a

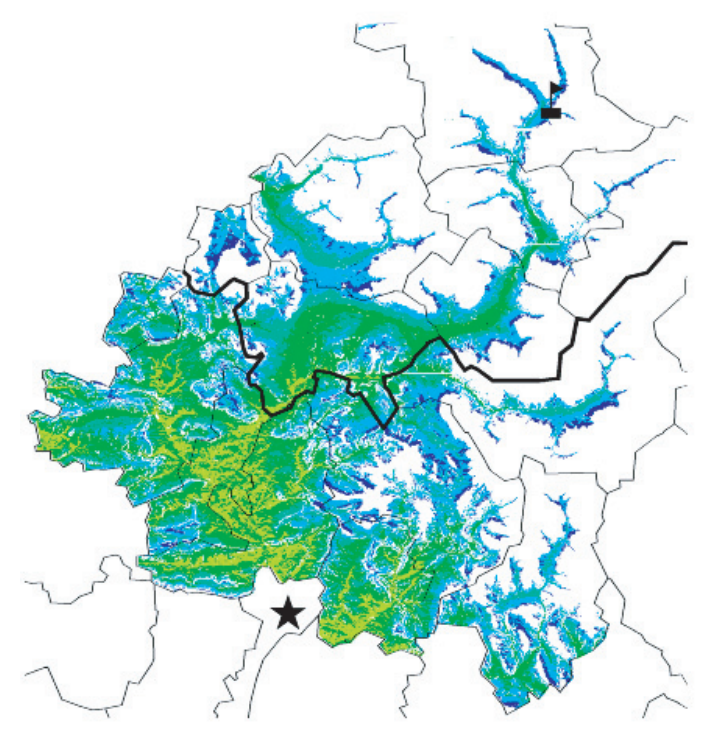

b

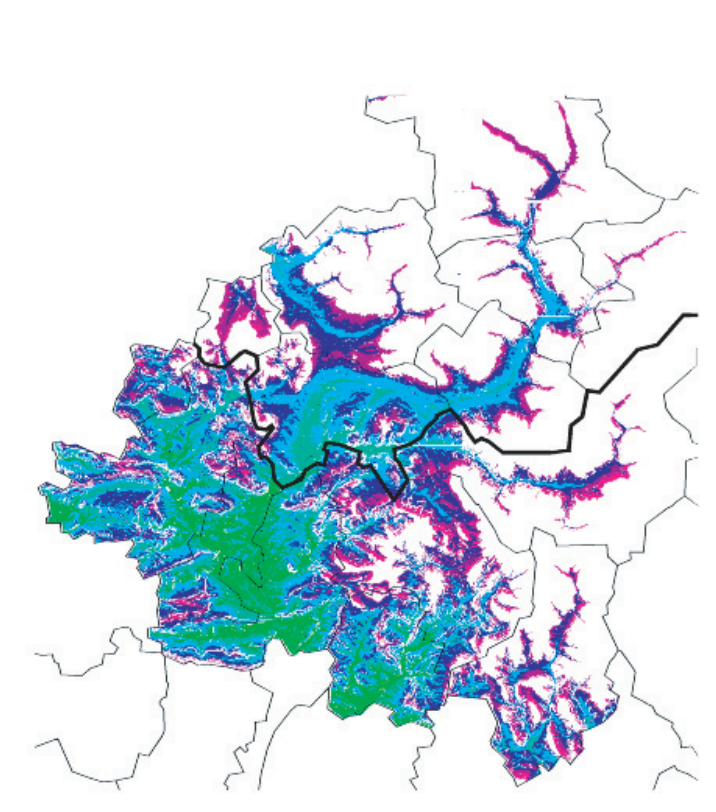

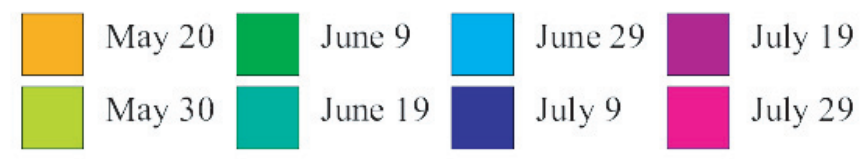

$\mathrm{c}$

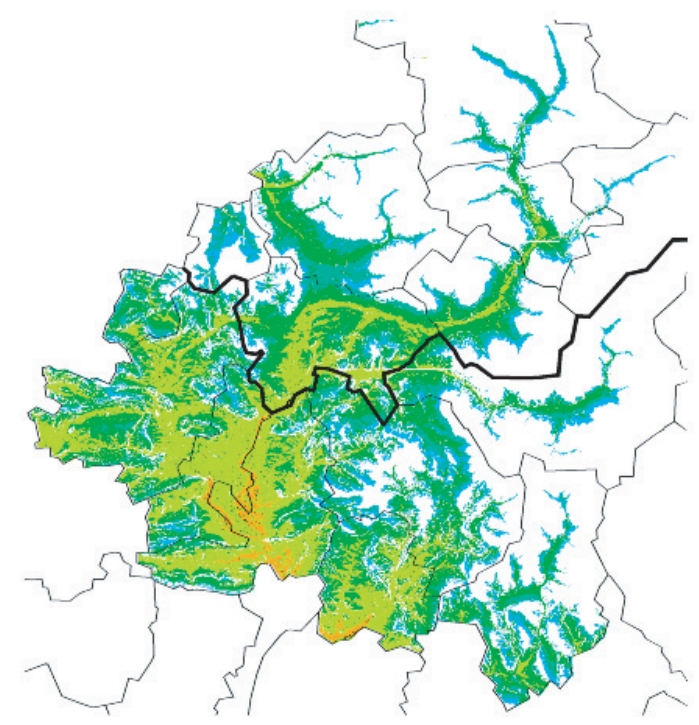

c

July 29

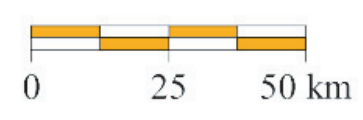

d

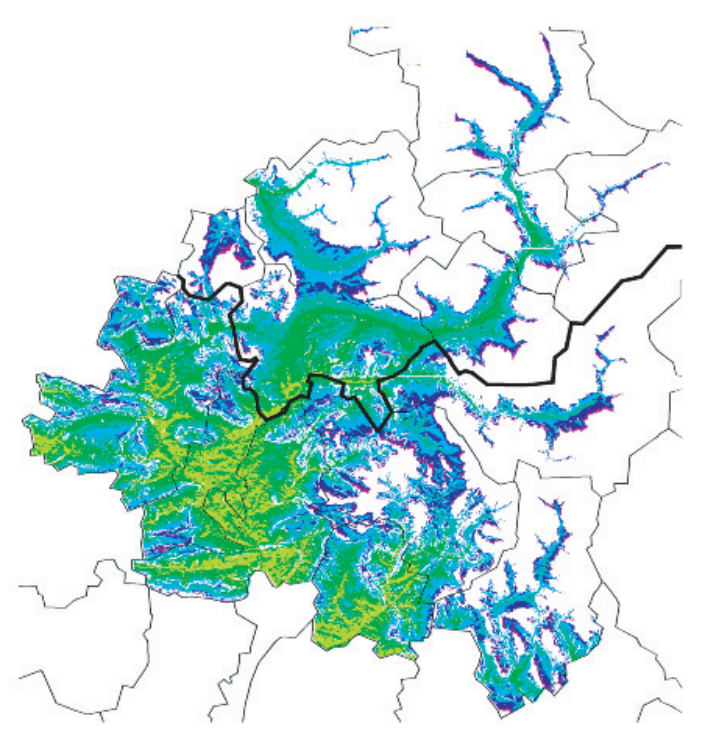

Annex B. Potential spatialized simulated first cutting dates for grassland: (a) gramineous, historic series, (b) alfalfa, historic series, (c) gramineous, scenario 1, (d) alfalfa, scenario 1. The bold line separates northern and southern zones. The flag and the star locate, respectively, Briançon and St Auban meteorological stations. 
a

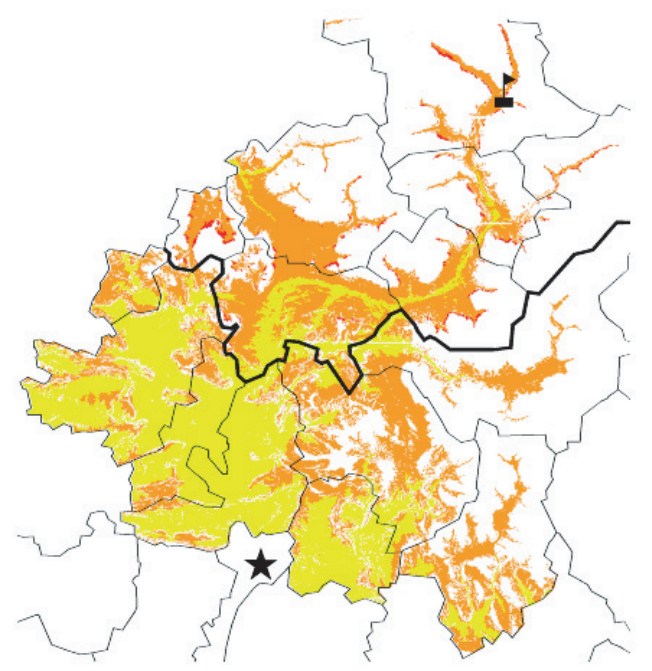

$\square$ No data $\square 2$ cuts $\square 4$ cuts
1 cut $\square 3$ cuts

$\mathrm{c}$

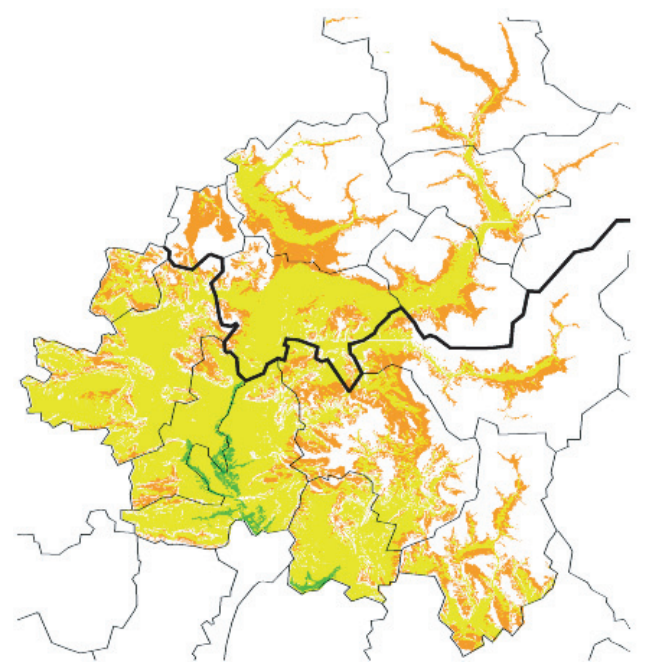

b
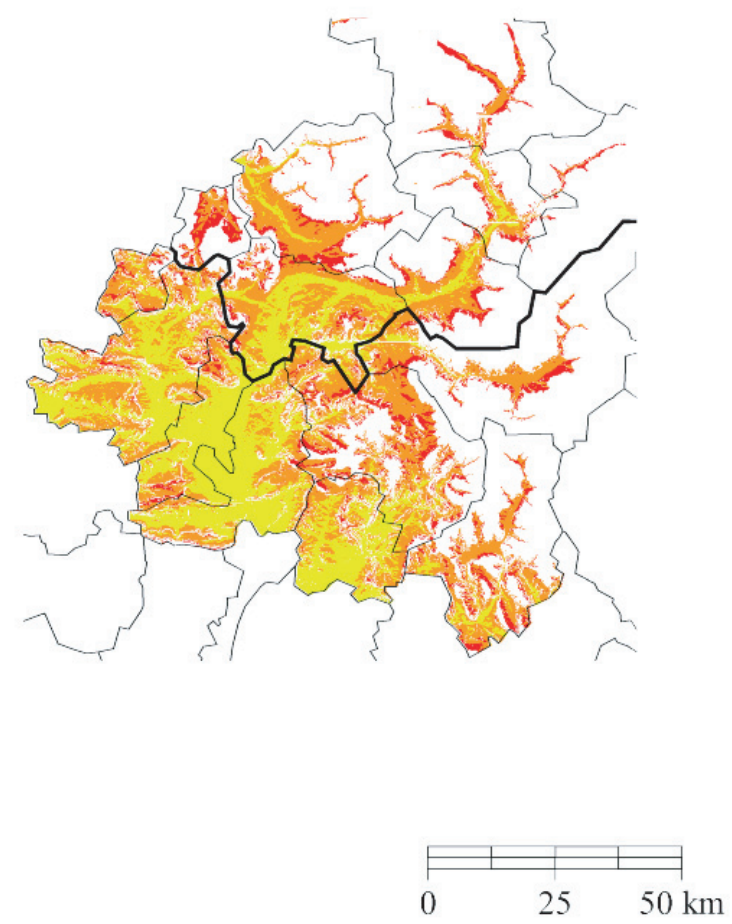

d

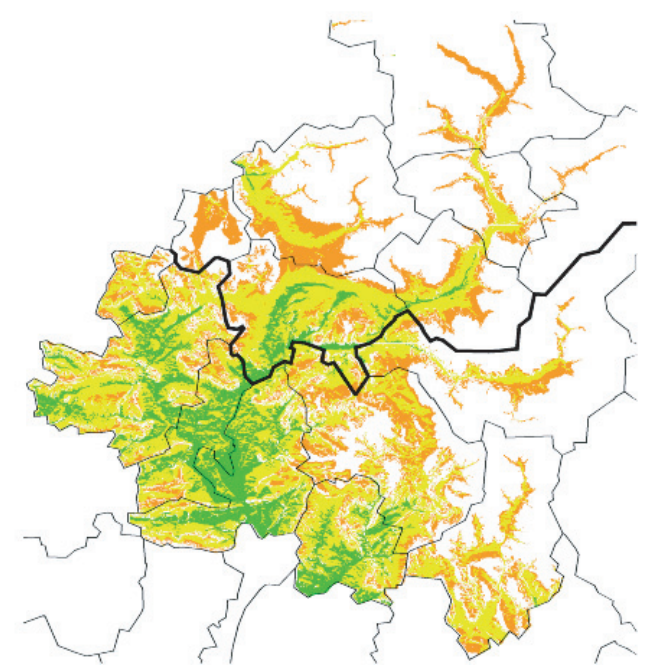

Annex C. Potential spatialized simulated cut number for grassland: (a) gramineous, historic series, (b) alfalfa, historic series, (c) gramineous, scenario 1, (d) alfalfa, scenario 1. The bold line separates northern and southern zones. The flag and the star locate, respectively, Briançon and St Auban meteorological stations.

can be expressed by the number of cuts in terms of production duration (Annex C). The predicted increase for alfalfa was remarkable: where just one summer cut was possible with the historic series, some two or three cuts could be expected with the simulated scenario. In the southern zone, four cuts of gramineous crops might be possible on occasion, but this would affect only around $20 \%$ of the surface area for alfalfa (because of shorter growing cycles). 


\subsection{General discussion}

The results of the last ten-year series were in line with the IPCC report. Over the past ten years, climate changes have been significant and their effects on crop behavior have tended to validate climatic scenarios.

Our results provide convincing evidence of a global increase in forage potential, even though different explanations are possible in the two studied areas. In the northern zone, the increase arose from the possibility of cultivating fields at higher altitudes for both grasslands and silage maize crops. In the southern zone, characterized by lower altitudes, the increase depended on the possibility of growing maize varieties with longer cycles and cutting forage more frequently. However, in both areas, the potential increase was always associated with broader ranges of forage types available to animals: gramineous, legumes, and long- and short-cycle maize crops.

\section{CONCLUSION}

The novelty of this work relies on the use of many methods and tools in combination (the GCM outputs, climatic generator, crop model, GIS and Altitude Thermal Gradient Model). Another originality within the framework of climate change impact studies is the focusing on agricultural marginal zones such as uplands.

Our study focused on temperature change, which is justified by current climate trends. To complete this work, it would be necessary to introduce, as STICS inputs, variations in other climatic factors (rainfall and radiation) and predictions of increased $\left[\mathrm{CO}_{2}\right]$ levels. Indeed, rainfall may be a determinant factor in mountain forage systems without irrigation and for forage drying in the field [11]. In parallel with introducing rainfall parameters, the cutting date could be calculated within STICS as a function of no-rain days after cutting, which also increases forage conservation time. Finally, it might be interesting to introduce soil variations into such a study, in the knowledge that the soil may be deep in valley zones and superficial in mountainous areas (our soil assumption was intermediate).

This study allowed a synthesis of all temperature effects on crops, but only addressed potentialities of possible use for prospective analysis.

\section{REFERENCES}

[1] Antonioletti R., Contribution à l'étude du mont Ventoux. Note de l'INRA, Avignon, 1986

[2] Antonioletti R., Seguin B., Quelques éléments sur le climat du mont Ventoux, Bulletin Clim. et Agroclim. de Vaucluse, Avignon, 1988, pp. 26-34.

[3] Baragnon G., Analyse bayésienne rétrospective d'une rupture dans des séries phénologiques, INRA, Montpellier, 2003.

[4] Barthelet P., Bony S., Braconnot P., Braun A.., Cariolle D., Cohen-Solal E., Dufresne J.-L., Delecluse P., Deque M., Fairhead L., Filiberti M.-A., Forichon M., Grandpeix J.-Y., Guilyardi E., Houssais M.-N., Imbard M., Le Treut H., Levy C., Li Z.X., Madec G., Marquet P., Marti O., Planton S., Terray L., Thual O., Valcke S., Simulations couplées globales des changements climatiques associés à une augmentation de la teneur atmosphérique en $\mathrm{CO}_{2}$, C.R. Acad. Sci. Paris, Sér. II a 326 (1998) 677-684.
[5] Bolstad P.V., Swift L., Collins F., Régnière J., Measured and predicted air temperatures at basin regional scales in the southern Appalachian mountains, Agric. For. Meteorol. 91 (1998) 161-176.

[6] Bootsma A., Forage crop maturity zonation in the Atlantic region using growing degree-days, Can. J. Plant Sci. 64 (1984) 329-338.

[7] Brisson N., Mary B., Ripoche D., Jeuffroy M.H., Ruget F., Nicoullaud B., Gate P., Devienne-Barret F., Antonioletti R., Durr C., Richard G., Beaudoin N., Recous S., Tayot X., Plenet D., Cellier P., Machet J.P., Meynard J.M., Delecolle R., STICS: a generic model for simulating of crops and their water and nitrogen balances. I. Theory and parameterization applied to wheat and corn, Agronomie 18 (1998) 311-346.

[8] Brisson N., Domergue M., Phenological modeling and climate change impacts in orchards: examples of apple, peach and apricot trees in the Rhone Valley (France). Towards an operational system for monitoring, modeling, and forecasting of phenological changes and their socio-economic impacts, Environmental Systems Analysis Group, Wageningen, 2003.

[9] Brisson N., Gary C., Juste E., Roche R., Mary B., Ripoche D., Zimmer D., Sierra J., Bertuzzi P., Burger P., Bussière F., Cabidoche Y.M., Cellier P., Debaeke P., Gaudillère J.P., Hénault C., Maraux F., Seguin B., Sinoquet H., An overview of the crop model STICS, Eur. J. Agron. 18 (2003) 309-332.

[10] Choisnel E., Aspects topographiques : une méthodologie d'étude en région de moyenne montagne. Agrométéorologie des régions de moyenne montagne, Les colloques de l'INRA, Paris, 1986.

[11] Cooper G., Mac Gechan M.B., Implications of an altered climate for forage conservation, Agric. For. Meteorol. 79 (1996) 253-269.

[12] Davies A., Shao J., Brignall P., Bardgette R.D., Parry M.L., Pollock C.J., Specification of climatic sensitivity of forage maize to climate change, Grass Forage Sci. 51 (1996) 306-317.

[13] Delecolle R., Jayet P.A., Soussana J.F., Agriculture française et effet de serre : quelques éléments de réflexion. Impacts Potentiels du Changement Climatique en France au XXI ${ }^{\mathrm{e}}$ siècle, M.I.E.S., 2000, pp. 74-80.

[14] Douguedroit A., Les topoclimats thermiques de moyenne montagne. Agrométéorologie des régions de moyenne montagne, Les colloques de l'INRA, Toulouse, 1986, pp. 198-213.

[15] Fagerberg B., Phenological development in timothy, red clover and Lucerne, Acta Agric. Scand. 38 (1988) 159-170.

[16] Fleury P., La variabilité microclimatique en montagne, son expression par la phénologie du dactyle des prairies permanentes, département de recherches sur les systèmes agraires et le développement, 1985.

[17] Gillet M., Les graminées fourragères, description, fonctionnement, applications à la culture de l'herbe, Collection « Nature et Agriculture », Gauthier-Villars, Paris, 1979.

[18] Grand P., Référentiel fourrages, Provence Alpes Cote d'Azur, pratiques culturales et utilisations des fourrages observées dans les petites régions naturelles, références techniques pour l'élaboration de systèmes fourragers, Maison régionale de l'élevage, 1991.

[19] Guy P., Blondon F., Durand J., Action de la température et de la durée d'éclairement sur la croissance et la floraison de deux types éloignés de luzerne cultivée, Ann. Amélior. Plantes 21 (1971) 409-422.

[20] Guyot G., Climatologie de l'environnement : de la plante aux écosystèmes, Masson, Paris, 1997.

[21] IPCC, Climate change 2001: the scientific basis, 2001.

[22] Juin S., Impact du réchauffement climatique sur la répartition géographique et les calendriers de production de trois systèmes fourragers, Diplôme Agronomie Approfondie, Montpellier, 2001.

[23] Le Maho Y., Georges J.-Y., Réponses des écosystèmes marins et insulaires aux changements climatiques, Geoscience 335 (2003) $551-560$.

[24] Le Treut H., Les scénarios globaux de changement climatique et leurs incertitudes, Geoscience 335 (2003) 525-533.

[25] Leland Russell F., Svata M. Louda, Phenological synchrony in the prediction of insect; Herbivore impacts on native plant populations. Towards an operational system for monitoring, modeling, 
and forecasting of phenological changes and their socio-economic impacts, Environmental Systems Analysis Group, Wageningen, 2003.

[26] Lobell D.B., Asner G.P., Climate and management Contributions to recent Trends in US Agricultural Yields, Science 299 (2003) $10-32$.

[27] Lookingbill T.R., Urban D.L., Spatial estimation of air temperature differences for landscape-scale studies in mountain environments, Agric. For. Meteorol. 114 (2003) 141-151.

[28] Mavromatis T., Hansen J.W., Interannual variability characteristics and simulated crop responses of four stochastic weather generators, Agric. For. Meteorol. 109 (2001) 283-296.

[29] Niqueux M., Arnaud R., Étude du rythme de végétation des graminées fourragères : cas de la moyenne montagne, Fourrages 103 (1985) 31-54.

[30] Olesen J.E., Bindi M., Consequences of climate change for European agricultural productivity, land use and policy, Eur. J. Agron. 16 (2002) 239-262.

[31] Peiris D.R., Crawford J.W., Grashoff C., Jefferies R.A., Porter J.R., Marshall B., A simulation study of crop growth and development under climate change, Agric. For. Meteorol. 79 (1996) 271287.

[32] Penuelas J., Filella I., Stefanescu C., Llones L., Ogaya R., Plant and animal phenological change linked to recent and predicted climate change in Catalonia (NE Spain). Towards an operational system for monitoring, modeling, and forecasting of phenological changes and their socio-economic impacts, Environmental Systems Analysis Group Wageningen, 2003.

[33] Planton S., À l'échelle des continents ; le regard des modèles, Geoscience 335 (2003) 535-544.

[34] Reddy K.R., Hodges H.F., Climate change and the global crop productivity, CABI publishing, Wallingford, 2000.

[35] Riedo M., Gyalistras. D., Fischlin A., Fuhrer J., Using an ecosystem model linked to GCM-derived local weather scenarios to analyze effects of climate change and elevated $\mathrm{CO}_{2}$ on dry matter production and partitioning, and water use in temperate managed grasslands, Global Change Biol. 5 (1999) 213-223.

[36] Rosensweig C., Hiellel D., Climate change and global harvest, Oxford University Press, Oxford, 1998

[37] Rosenzweig C., Land-surface Model Development for the GISS GCM, J. Climate 10 (1997) 2040-2054.

[38] Ruget F., Delecolle R., Le Bas C., Dure M., Bonneviale N., Rabaud V., Donet I., Pérarnaud V., Panaigua S., Utilisation spatialisée de STICS, application à l'estimation et au suivi des productions fourragères françaises et à la détection de situations d'alerte, Colloque Ager-Mia, Montpellier, 2001.

[39] Ruget F., Duru M., Gastal F., Adaptation of an annual crop model (STICS) to a perennial crop: grassland. International symposium modeling cropping systems, 21-23 June 1999, Lleida (1999), pp. 111-112.

[40] Semenov M.A., Brooks R.J., Barrow E., Richardson C.W., Comparison of the WGEN and LARS-WG stochastic weather generators for diverse climates, Climate Res. 10 (1998) 95-107.

[41] Semenov M.A., Brooks R.J., Spatial interpolation of the LARSWG stochastic weather generator in the Great Britain, Climate Res. 11 (1999) 137-148.

[42] Sharratt B.S., Sheaffer C.C., Baker D.G., Base Temperature for Application of Growing-Degree-Day model to Field-Grown Alfalfa, Field Crops Res. 21 (1989) 95-102.

[43] Tayot X., Ruget F., Bouthier A., Lorgeou J., Lacroix B., Pons Y., STICS en Poitou-Charentes : calibration et validation sur maïs et sorgho, Perspect. Agric. 243 (1999) 87-95.

[44] Tessier L., Impact des changements climatiques en montagne. Impacts potentiels du changement climatique en France au $\mathrm{XXI}^{\mathrm{e}}$ siècle, M.I.E.S., 2000, pp. 99-103.

[45] Van Ittersum M.K., Donatelli M., Modeling cropping systems highlights of the symposium and preface to special issues, Eur. J. Agron. 18 (2003) 187-197.

[46] Yu O., Gintzburger G., Gounot M., Modèle de fonctionnement du dactyle en phase végétative. Approche morphologique, Oecol. Plant. 10 (1975) 107-139. 